\title{
Implementing Ayo Balik Natural Science Learning Model to Eighth-Grade Students of State Junior School
}

\author{
Achmad Fathoni \\ Universitas Muhammadiyah Surakarta \\ Ahmad Muhibbin, Zainal Arifin, Wahdan Najib Habiby and Shokhifatun \\ Universitas Muhammadiyah Surakarta
}

\begin{abstract}
The research aims at describing the implementation of Ayo Balik natural science learning model to the eighth-grade students of SMP Negeri 1 State Junior High School, Semarang regency, Central Java, Indonesia. It used a qualitative approach. The techniques of data collection consisted of limited, wide, and validity tests. The data validation used theory and data/source triangulation technique. The data analysis employed an interactive model, including data collection, data reduction, data presentation, and conclusion. The results of the study show that 1) Ayo Balik model could develop the students' cognition, affection, psychomotor competencies, and academic activities. 2) The model could encourage among students to welcome and tolerate the difference in races, religions, academics, and social strata. 3) The model could develop the students' social skills. It can be concluded that Ayo Balik natural science learning model was said to be effective and efficient for increasing the students' academic performances. Similarly, it can encourage the students to play an actively cooperative and collaborative role in a learning process, on one hand. On the other hand, the teachers do not have any difficulties in a learning activity. They can be easy to discuss them and can create a fun learning and varied atmosphere.
\end{abstract}

Keywords: academic activities; Ayo Balik learning model; competencies; Junior High school students; natural science.

\section{Introduction}

Learning is a process of transferring knowledge from teachers to students. It means a process of acquiring knowledge, skill, behavior, or values of attitude. It can also be seen as a process of developing knowledge skill, behavior, and value. Hariyanto, Soetarno Joyoatmojo, Joko Nurkamto \& Gunarhadi (2019) stated that learning is a process to gain new information through an interaction of someone 
with the environment. The information can be developed through a learning process. Instruction is a chain of activities that influence students' behavior. Learning is an interaction between a teacher and student or two or more students. However, implementing a learning strategy often causes a problem. One of the alternatives to overcome the problem is implementing Ayo Balik learning model. It is a cooperative and collaborative learning type of a modified make a match. This model can encourage students to play an active role in a learning process and increase their academic achievements and performances.

For transferring knowledge, skill, behavior, or values to students, however, teachers should be able to employ a variety of appropriate learning models in consideration with their characteristics so that a learning objective can be achieved. As a process of students' resources development, therefore, learning must be running effectively and efficiently so it will increase students' academic performance and achievement and learning outcome as stated. On one hand, therefore, each teacher must be able to manage a learning process in the classroom. As a facilitator, teachers must be able to use or employ an excellent learning model that can motivate or encourage students to take a subject or course in the classroom effectively and efficiently and develop their cognitive, affective, and psychomotor competencies. They must build and promote their students' spirit to be creative and innovative. Likewise, they must be successful in making students develop more knowledgeable, skillful, and creative as well as innovative.

On the other hand, students must be able to position by themselves as an active, creative, and innovative learner for developing their values and attitude, knowledge, and skill of a subject or course as described in competencies and learning objectives. As a learner, in other words, students should not serve as an object of a subject or course learning process that merely acts as a silent person. They have to be a creative, communicative, critical, collaborative, innovative, and cooperative learner with learning atmosphere or environment and learning sources.

Natural science is one of the courses for Junior High School students must take. In comparison with social science, in the early survey, they regarded it to be a more difficult subject for most of the students. In addition, they think that it has been included as an uninteresting or boring material because they have been unfamiliar with its terminologies. It is hard to memorize and uses many formulas for solving a problem.

Such a mindset can cause a low achievement or motivation of natural science course in terms of cognitive, affective, and psychomotor competencies. The difficulty to understand this course can also cause students' low motivation in taking the class of it. According to Johnson (2015, pp. 83-98), increasing students' learning motivation was influenced by the type of learning materials, contents, characteristics, materials, individual, and group in the classroom. Therefore, it is a teacher's responsibility as an agent of a student's conceptual 
change for removing the mindset by running a learning process or using another learning process method involving students in taking an active role in the class.

The students' mindset may generally result from a natural science teacher. Most of the natural science teachers have been employing a less innovative and monotonous or boring strategy or model. The characteristics of the strategy make students passive/silent and less interesting and less motivated in a learning activity. Instructional materials are seldom discussed in collaboration with students so that a natural science course is difficult to understand by them and they feel bored with the subject so that they are low in academic achievement and performance of the course.

In the early observation at the students of SMP Negeri 1 State Junior High School, Semarang regency, most of them had not understood an instructional material of natural science they would discuss with their teacher. They tendentiously acted as an inactive or silent and less motivated subject as well as a passive student in a natural science learning process. On one hand, they were playing an inactive role in understanding a knowledge structure that is conveyed by a teacher whereas, on the other hand, the teacher was an early and substantial source in a natural science learning process. Similarly, the students could not function as a learning subject and a teacher's creativity in understanding a strategy might be stated to be low. These could cause a learning atmosphere or environment to be boring or not to be conducive.

The implementation of the learning strategy showed the result of the Grade Controlling Test to the students of SMP Negeri 1 State Junior High School, Semarang regency. It is found that out of 282 students, $149(52.83 \%)$ of them achieved Kriteria Ketuntasan Minimal [Minimal Criteria of the Score] and 133 $(47.17 \%)$ of them did not achieve it. The criteria did not meet the qualification as stated by the National Education Department since the Minimal Criteria of a Score must be $85 \%$. Based on the data, it can be concluded that the strategy of natural science learning model does not run effectively and efficiently. So, it is immediately necessary to use another learning strategy. The teacher should implement a creative and innovative strategy so that it can produce a learning activity to be more meaningful and helpful for students.

In the early observation results, it is very greatly necessary to implement a fun model or strategy. One of the alternatives to overcome the problem is implementing Ayo Balik learning model. It is a cooperative or active learning type of a modified make a match. It is assumed that the strategy will be helpful and meaningful for teachers and students to understand a subject or course collaboratively and cooperatively. As a facilitator, on one hand, teachers will get any new experience. It can be employed more effectively and efficiently and can be used for any course. Besides, teachers will be easy to monitor a student's activity.

On the other hand, students will be in a fun atmosphere and environment of learning activity. Similarly, it will build and develop any cooperation and 
collaboration between teachers and students more intensely. The active learning pedagogic uses reduce failure rates in STEM (science, technology, engineering, and mathematics) courses that substantially increase the students' retention in STEM majors (Freeman S., Eddy, S. L., McDonough, M., Smith, M. K., Okoroafor, N., Jordt, H., \& Wenderoth, M. P., 2014; Freeman, Scott., Haak, David., Wenderoth, and Mary Pat, 2011; Graham, Mark J., Frederick, Jennifer Byars-Winston., Angela Hunter., and Anne Barrie Handelsman, Jo, 2013). The present research paper describes implementing Ayo Balik learning model of natural science course at SMP Negeri 1 State Junior High School students, Semarang regency. The strategy is an active learning model. Active learning covers a variety of techniques that explicitly encourages students to take an active role in the class material and instructors answer questions, work problems, and complete peer discussions (Wieman, 2014).

\section{Literature Reviews}

Ayo Balik is a kind of a cooperative learning model. This refers to a modified make a match modified. The difference between make a match learning model and Ayo Balik one is closely related to a way of learning. In comparison with conventional and make a match models, Ayo Balik one is an alternative learning model to encourage students' academic performances more maximally by referring to a learning objective and outcome. In essence, the difference in the two models from Ayo Balik model takes place in the way of a class management process.

\section{Make a Match Learning Model}

Make a match is a teaching technique by finding a pair or partner. It is a fun, collaborative, and cooperative learning model. It is one of the learning models for increasing students' academic competency. It is a conceptual approach that teaches students to understand concepts actively, creatively, effectively, and interactively. It aims at giving training to students so that they can comprehend an instructional material more easily. It focuses on the discussion of previous instructional materials. The research by Wastawan, Sutarsyah, \& Sudirman (2014) shows the result of the reading study by using make a match type of cooperative learning. it is suggested that there was a significant difference in students' reading comprehension $(\mathrm{p}<0.05, \mathrm{p}=0.00)$. The average of the posttest score (64.79) was higher than that of the pre-test (51.48) and it has a gain of 13.31. There is an increase in students' reading comprehension achievement by using make a match type of cooperative learning.

Imas and Berlin Sani (2016) suggest that make a match learning model can produce a more helpful and meaningful atmosphere or environment for students. Similarly, it can give several benefits. For example, the model can increase students' learning activity cognitively, affectively, and physically. It can effectively be used to give training in students' discipline for time management in learning and thinking about getting a partner quickly. It can increase students to understand instructional material. It can increase students' motivation and learning achievement. It can function as a facility to train students' selfconfidence for presentation. It can make students produce a fun and active 
learning atmosphere and environment. Finally, it can build and develop dynamic cooperation and collaboration among students.

Soleha (2016) proposes that make a match type is a learning model that emphasizes a collaborative- and interactive-social capacity and critical-thinking one. In the early stage, the implementation of the model begins with a technique, namely students get a pair of an answer and question card before the time ends. The students who make their cards match the answer or question will get any point (score). According to Rusman (2011), make a match model is a kind of cooperative learning. By employing a kind of cooperative learning model, make a match learning model can improve the quality of social study learning of the fifth-grade students of SDN Kalibanteng Kidul 01 Semarang. It is recommended that a make a match cooperative model needs applying and developing since it can improve teacher's skill and students' activity and learning achievement so it can influence the improvement of social study learning (Febriana, 2011).

Make a match is a learning model by using cards. The stages of make a match learning can be described as follows. Teachers prepare some cards of concept or topic for review sessions and some other cards of answer cards. Each student gets a card; each student thinks about the answer/question card; each student gets a partner/pair whose card is suitable to his or her answer/question card; and each student can match his or her card before the time ends and he or she will get any point (score). After the stage, the cards are shuffled so that students will get any different cards. The following stages can be the same as the previous ones until concluding.

Huda (2013) stated that make a match cooperative learning model takes a positive and meaningful effect on increasing in students' learning activity cognitively and physically and being fun because of an available entertaining element. In addition, it increases students' understanding of instructional materials and learning motivation, self-confidence in the effective presentation, and students' discipline and effectiveness in a learning activity. However, some weaknesses of the learning model include as follows. 1) If the model is not in good preparation, it will spend more time. 2) In the early learning model, many students will seem shy in collaboration with another different gender. 3) If a teacher does not manage students well, more students will not give any attention to pair presentation. 4) Teachers must give any punishment wisely and carefully for students who do not get any partner or pair. 5) If using the method continuously, it will make teachers and students feel very bored with a course.

\section{Ayo Balik Learning Model}

Conceptually, Ayo Balik learning model is said to be make a match cooperative learning, although it has been modified. It is implemented in a group of 4-5 students. Each group will get an Information and Communication Technology (ICT) learning with the model. It consists of three envelopes and each comprises an answer sheet card. An answer sheet amounts to 10 cards: five cards contain answers and others contain distractors. The opposite of each answer sheet card is inscribed with a word, question sheet, and question card. 
The difference between make a match learning and Ayo Balik one is closely related to a way of learning. In make a match learning, there are two groups of students: one holds a question card and the other holds an answer card. In the learning process, a question cardholder thinks about its answer and gets an answer holder. In Ayo Balik learning model, each student collaborates to understand a question and thinks about its answer; then it is attached to an answer sheet. The two learning models are the same in terms of solving an answer to a question.

Ayo Balik learning model emphasizes a good collaboration among members of a team. An individual member is responsible for the same task as another one. This model will produce any situation where a successful individual is highly determined or influenced by a successful group. It aims at increasing students' cognitive achievement or academic tasks. The students with higher capacity will be a speaker for those with lower capacity. It also aims at tolerating and welcoming any differences among students. The difference can be related to race, religion, academic, and social position. Similarly, the purpose of the model is developing students' social skills, namely sharing with others, asking more questions, tolerating other ideas, thinking about anything, and collaborating with others in a group.

The model may be very beneficial for teachers and students. On one hand, teachers get any new experience. Learning will run more effectively and efficiently. They can monitor students' learning activity more easily and effectively. On the other hand, students who will be in a happy and fun atmosphere and environment will grow and develop in a learning process. It will build and develop some collaboration among students and make a learning activity in more dynamic and it takes an effect on the deep preparation of ICT learning. In its process, students have got some directions and guidance from teachers previously. In essence, it needs to be prepared as well as possible so that it can achieve a learning objective as stated.

\section{Research Method}

The research used a qualitative and experiment approach. The characteristics of the qualitative are as follows. 1) It is natural where the researcher serves as a key instrument. 2) It is descriptive. 3) It focuses on the process. 4) The data are analyzed inductively. 5) It emphasizes on a meaning (Sugiyono, 2007). The qualitative approach was employed by understanding the conceptual model of Ayo Balik natural science learning more deeply and describing the subjects' characteristics and learning problems. The quantitative one was applied in the process of research design, data analysis, and conclusion. The research emphasized on understanding a meaning closely related to values, discussing a process, describing and interpreting meaning, and using multi-methods. According to Roestiyah (2012), an experimental method is a learning strategy on how students make an experiment, observe its process, and report its results. Finally, the results of the observation are reported and evaluated by teachers in the classroom. 
The subject of the research is Ayo Balik learning model of natural sciences at the eight-grade students of VIII SMP Negeri 1 State Junior High School, Semarang regency, Central Java, Indonesia. The study was participated by 31 students. In the study, the researchers in collaboration with the teachers served as an observer, identified the problem statements, and made a concept of lesson study. The researchers served as a key instrument as stated by Bogdan, R.C, and Biklen (1998), Guba, E. G., dan Lincoln (1981). As a key instrument, they directly adapted to responding any interaction among the subjects so that they could keep a unity, develop fundamental knowledge, make an information process as soon as possible, and observe a unique response as proposed by Guba, E. G., and Lincoln (1981).

The data source covered the principal, vice-principal of curriculum, teachers, and eighth-grade students of VIII SMP Negeri 1 State Junior High School, Semarang regency. The data of the research included the words, phrases, and sentences that resulted from interviews, observations, analysis results, and documentation. The data analysis included two kinds of site test and experiment test results. The data analysis of research sites was formulating the results of the study. It used an interactive model as suggested by Miles, M. B., and Huberman (2007). The results of the experiment test will be said to be effective if the scoring average of learning achievement reached the minimal criteria of the score at $80 \%$. There is a real difference in the pretest and posttest by an SPSS statistic test if the score of the significance (2-tailed) or the significance of the pretest and posttest at $0.000<$ 0.05 and minimal learning level are categorized to be active (60-79) (Aqib, 2009). The pretest was used for understanding the students' early abilities. It was used for designing Ayo Balik learning model. After treatment, the students were tested to understand the minimal criteria of the score. The results of the posttest were used for evaluating and revising the learning model.

The data validation is essential in the study because it will ensure the reliability of the data. The data of the study were qualitative and the researchers were a key instrument. For this, the data validation test and reliability of the instrument were employed to check and test the data (Guba, E. G., dan Lincoln, 1981). In qualitative research, the data validation uses the criteria of credibility, transferability, dependability, and conformability (Ulfatin, 2013).

The data validation of the research used triangulation technique, member check, and fellow discussion. It employed data/source triangulation. The technique of the data collection was employed to compare the data or information gathered with other techniques. The source triangulation was applied for accurate data or information from the informants.

\section{Results and Discussion}

The use of Employing Ayo Balik natural science learning model at the eighthgrade students of SMP Negeri 1 State Junior High School, Semarang regency can increase the students' cognition, affection, and psychomotor competencies and learning achievement for their academic tasks. They can serve as a facilitator for their lower fellow friends. In addition, among students can tolerate and 
welcome the difference in academic skill, race, religion, and social position, and develop their social skill in sharing with others such as welcoming their fellow friends' ideas, and think critically and collaboratively. In other words, the students' behavior and attitude are a change in the competencies of cognition, affection, and psychomotor.

Stauffer (2013) suggested that an effect of cooperative learning on academic achievement, social interaction, and social behavior positively influences academic achievement. Make a match cooperative learning model and conventional model could increase the students' ability to observe, communicate, asses, classify, and make a conclusion. So, it can be concluded that there is a real difference between the results of Ayo Balik natural science learning model at the pretest data and those of posttest data. In terms of Ayo Balik natural science active learning model, it is stated that it is effectively used for the eighth grade natural science at the students of SMP Negeri 1 State Junior High School, Semarang regency.

The results of Ayo Balik natural science learning model at the eighth-grade students of SMP Negeri 1 State Junior High School show as follows. It could increase a learning achievement: a) the result of the limited test I did not reach a minimal qualification of $80 \%$ and $b$ ) that of the limited test II showed that a score of learning achievement only reached $67 \%$. It does not meet the minimal criteria of the score at $80 \%$. The wide experiment test found that the mean score for learning achievement reached 85.65. It is in the category beyond the minimal criteria of the score as determined at 75 and $100 \%$ for the minimal criteria of score at $80 \%$.

Based on the data, the learning achievement increased for each experiment. The active learning score was found at the limited experiments I, II, and III (wide limited experiment). (a) The active learning at the limited experiment I found the mean of active learning scores at 77.08. It is in an active category (60 -70). (2) At the limited experiment II, it is found the mean of active learning scores at 79.17. It is also in the active category $(60-70)$. At the wide limited experiment, it was a mean of active learning scores at 83.33 . It is in the very active category $(\geq 80) . b$ ) Based on the learning achievement of pretest and posttest, it is found at the learning of the wide experiment. The results of the pretest and posttest were tested with the T-test for understanding between the pretest and posttest. The results of the T-test for the pretest and posttest were a mean of the pretest at 64.52 and the result of the posttest at 85.48 (see Table 2). The deviation standards of the pretest and posttest were 10.74824 and 9.34120 respectively. The standards of error mean for the pretest and posttest were 1.03044 and 1.67773 with the significance at 0.16 and the value of the significance (2-tailed) at 0.000 . It means that the value of the significance at 0.16 is higher than 0.05 . Due to the higher value, there is a correlation between the pretest and posttest. The value of the significance (2-tailed) is $0.000<0.05$. 
Table 1: Results of pretest and posttest

\begin{tabular}{|c|c|c|c|}
\hline No. & Students' names & $\begin{array}{c}\text { Scores of } \\
\text { pretest }\end{array}$ & $\begin{array}{c}\text { Scores of } \\
\text { posttest }\end{array}$ \\
\hline 1 & Ahmad Rifgi & 35 & 65 \\
\hline 2 & Alfan Efendi & 65 & 90 \\
\hline 3 & Angelia Merici & 55 & 75 \\
\hline 4 & Apriliana Dwi Utami & 50 & 85 \\
\hline 5 & Ari Wibowo & 55 & 100 \\
\hline 6 & Bayu Anuur & 50 & 70 \\
\hline 7 & Bayu Kristianto & 55 & 95 \\
\hline 8 & Danesa kharisma Putra & 80 & 80 \\
\hline 9 & Didi Sugiarto & 65 & 85 \\
\hline 10 & Daiaya Pangestuti & 65 & 85 \\
\hline 11 & Eka Defta Setyowati & 75 & 85 \\
\hline 12 & Febri Kurniawan & 60 & 95 \\
\hline 13 & Habib Candra Himawan & 65 & 95 \\
\hline 14 & hanif Dida Hayuna & 75 & 80 \\
\hline 15 & Intania grandina Ebis Manora & 70 & 85 \\
\hline 16 & Jho Ananda Bagus Firmansyah & 78 & 100 \\
\hline 17 & Lusia Ria Tri Nani & 70 & 90 \\
\hline 18 & Margaretha Dea Priana & 75 & 80 \\
\hline 19 & Muhamad Ramadhan Ali Firdaus & 65 & 70 \\
\hline 20 & Nafla Kapila & 55 & 85 \\
\hline 21 & Rafi Ilham Muhamad & 60 & 85 \\
\hline 22 & Rida Santika Dewi & 50 & 70 \\
\hline 23 & Prisca Setya Ramdhani & 80 & 100 \\
\hline 24 & Salma Dwi Selfiana & 60 & 80 \\
\hline 25 & Sanju Sandika & 75 & 80 \\
\hline 26 & Satria Bekti Wicaksoni & 75 & 100 \\
\hline 27 & Sekar mayang Pusporini & 60 & 85 \\
\hline 28 & Sarif Amirul Wicaksono & 60 & 90 \\
\hline 29 & Tegar Nur Arifin & 75 & 85 \\
\hline 30 & Teresia Eli Winasti & 75 & 90 \\
\hline 31 & Ulva Novita Dewi & 67 & 90 \\
\hline
\end{tabular}

Table 2 : Description of pretest and posttest

\begin{tabular}{|c|c|c|}
\hline Lowest Scores & 35 & 65 \\
\hline Highest Scores & 80 & 100 \\
\hline Mean & 64.52 & 85.48 \\
\hline Students' achieved minimal criteria of scores & 9 & 28 \\
\hline Students' unachieved minimal criteria of scores & 22 & 3 \\
\hline Achievement percentage & 29.03 & 90.32 \\
\hline
\end{tabular}


Graphic 1: Score mean of pretest and posttest

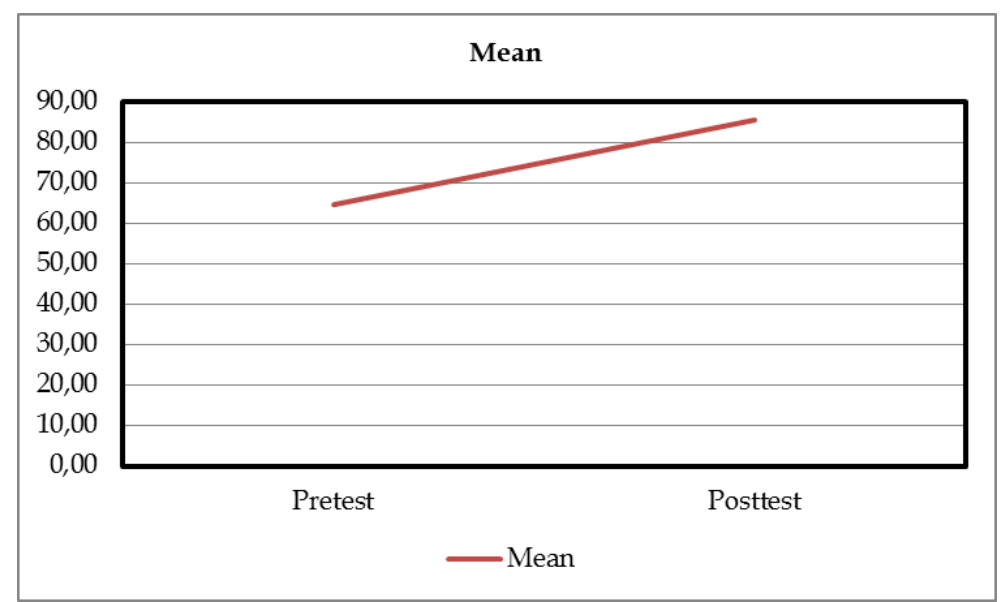

Graphic 2: Lowest and highest scores

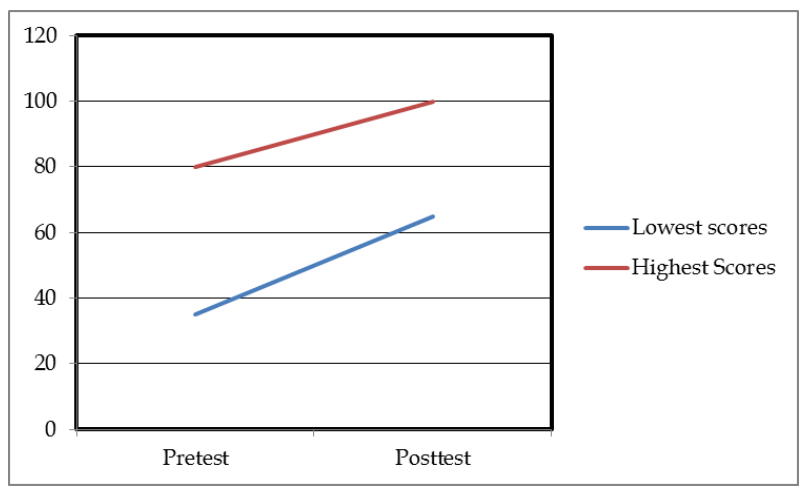

The result is relevant to that of the research by Apriyani, Al. Maryanto, and Sabar Nurohman (2016), showing that a cognitive learning achievement before the experiment averaged 30.80 and the control group averaged 31.40. After the research, the experiment reached 72.80 and the control group achieved 67.60. It coul be concluded that make a match learning model could increase a natural science learning achievement. The research by Agata and Sujadi (2017) stated that make a match learning model could increase an active learning and learning achievement. The active learning of Circle 1 was $57.10 \%$. It increased at $75.98 \%$ at Circle II. The mean of learning achievement at pre-Circle, Circle I, and Circle II was $39.90,64.77$, and 71.26 respectively.

The results of the research are greatly relevant to that of the research by Novianti (2017). It can be concluded that make a match as a sort of cooperative learning model could increase the ability of mathematic communication. It used a quantitative approach with the pretest-posttest control group design. The results of the research show that the teachers' activities got a score of $90 \%$ and the students' activities reached the score of $88.57 \%$. The result of the conventional class observation for the teachers' activities achieved the score of $87.78 \%$ and the students' activities at $85.56 \%$. Based on the results, therefore, the teachers' and students' activities can be high by using make a match cooperative learning model. 


\section{Conclusion}

The research paper presents the use of Ayo Balik natural science learning model for the students of Junior High School. The topic of the research derives from the low minimal criteria of the scores of the students' natural science course as one of the obligatory subjects in a secondary or junior high school. For this, the research paper describes the problems that are closely related to the low criteria of the score and find some solutions to them.

Based on the data analysis, the results of the research and the discussion of Ayo Balik Natural Science learning model at the eighth-grade students of SMP Negeri 1 State Junior High School as described above, it can be concluded as follows.

a. The use of Ayo Balik natural science learning model at the eighth grade students of SMP Negeri1 Bawen State Junior High School, Semarang regency is to increase the students' cognition and learning achievement for their academic tasks. They can serve as a facilitator for their lower fellow friends. In addition, it can tolerate the difference in academic skill, race, religion, and social position and develop their social skill in sharing with others such as welcoming their fellow friends' ideas, and think critically and think collaboratively.

b. The results of Ayo Balik natural science learning model can be stated to be valid and effective. In terms of the validity, the expert in the media is in a very high category. The expert in the materials is in a high category. Similarly, the teachers' responses and students' ones are in the high category.

Regards the effectiveness, it is found the data analysis of learning achievement and active learning. Using Ayo Balik natural science learning model is said to be effective. It is based on the limited experiment I wide experiment and II. By applying the model, likewise, the students take an active role in a learning process. It can also encourage the students to think critically, help them understand the materials. The teachers do not have any difficulty in a learning activity. They can be easy to discuss them and can create a fun learning and varied atmosphere.

The research is merely restricted to the students of SMP Negeri 1 State Junior High School, Semarang regency, Central Java, Indonesia. In further researches, it is recommended that other researchers can develop subjects or courses of different elementary schools and state and private secondary (junior or high) schools. In more particular, other researchers can develop a natural science course for further studies.

\section{Acknowledgments}

We are very grateful to the Rector of Universitas Muhammadiyah Surakarta that has funded the research. Also, we appreciate the experts in education who have reviewed our research paper. 


\section{References}

Herlikano, R. M. A. and Sujadi A. A. (2017). Peningkatan keaktifan dan hasil belajar matematika menggunakan make a match siswa kelas VIII A SMPN 2 Temon [Increasing activeness and cognitive learning outcome of mathematics using model of make a match type to the A eight-grade students of SMPN 2 State Junior High School in Temon]. UNION: Jurnal Pendidikan Matematika, 5(2), 121128.

Apriyani, A., Maryanto, A. and Nurohman, S. (2016). Pengaruh model cooperative learning tipe make a match dalam pembelajaran IPA terhadap keterampilan sosial dan hasil belajar kognitif siswa SMP [The influence of cooperative learning model of make a match type for natural science learning on Junior High School students' social skill and cognitive learning outcome]. Jurnal Pendidikan Ilmu Pengetahuan Alam, 5(9), 1-7.

Aqib, Z. (2009). Penelitian tindakan kelas [Class-action research]. Bandung: Yrama Widya.

Bogdan, R. C. and Biklen, S. K. (1998). Qualitative research for education: An introduction to theory and methods (third edition). Boston: Ally and Bacon, Inc.

Febriana, A. (2011). Penerapan model pembelajaran koperatif tipe make a match untuk meningkatkan kualitas pembelajaran IPS siswa kelas V SDN Kalibanteng Kidul 01 Kota Semarang [The implementation of cooperative learning model of make a match type for increasing social science learning quality to the fifth grade students of SDN State Elementary School, Kalibanteng Kidul 01 Kota Semarang]. KREATIF: Jurnal Kependidikan Dasar, 1(2), 151-161.

Freeman, S., Eddy, S. L., McDonough, M., Smith, M. K., Okoroafor, N., Jordt, H. and Wenderoth, M. P. (2014). Active learning increases student performance in science, engineering, and mathematics. Proceedings of the National Academy of Sciences of the United States of America, 111(23), 8410-8415. https://doi.org/10.1073/pnas.1319030111

Freeman, S., Haak, D. and Wenderoth, M. P. (2011). Increased course structure improves performance in introductory biology. CBE Life Sciences Education, 10(2), 175-186. https://doi.org/10.1187/cbe.10-08-0105

Graham, M. J., Frederick, J., Winston, A. B., Hunter, A. B. and Handelsman, J. (2013). Increasing persistence of college students in STEM. Science, 341(6153), 1455-1456. https:// doi.org/10.1126/science.1240487

Guba, E. G. and Lincoln, Y. S. (1981). Effective evaluation: Improving the usefulness of evaluation results through responsive and naturalistic approaches. San Fransisco: Jossey-Bas Publishers.

Hariyanto, H., Soetarno, J., Joko, N. and Gunarhadi, G. (2019). Developing inquiry-based learning materials to promote students' academic achievement. International Journal of Learning, Teaching, and Educational Research, 18(1), 50-61. https://doi.org/10.26803/ijlter.18.1.4

Huda, M. (2013). Model-model pengajaran dan pembelajaran [Teaching and learning models]. Yogyakarta: Pustaka Pelajar.

Imas, K. and Berlin. S. (2016). Ragam pengembangan model pembelajaran untuk peningkatan profesionalitas guru [The type of learning model development for increasing teachers' professional]. Jakarta: Kata Pena R.

Johnson, M. (2015). A qualitative examination of ESP instructional materials and motivational engagement. ESP Today, 3(1), 83-98.

Miles, M. B. and Huberman, A. M. (2007). Qualitative data analysis. London: Sage publications.

Novianti, N. (2017). Penerapan model pembelajaran make a match terhadap 
kemampuan komunikasi matematis siswa dengan menggunakan geoboard pada materi bangun datar di kelas VII SMP negeri 2 Bireuen [The implementation of make a match learning model by using geo-board for two dimensional-figure materials to the seventh grade students' mathematic communication skill of SMP 2 State Junior High School, Bireuen]. Variasi, 9(1), 16-22.

Roestiyah, N. K. (2012). Strategi belajar mengajar [Teaching and learning strategy]. Jakarta: Rineka Cipta.

Rusman, R. (2011). Model-model pembelajaran mengembangkan profesionalisme guru [Learning models for teachers' professional development]. Jakarta: Rajawali Pers.

Soleha, S. (2016). Penerapan model pembelajaran kooperatif tipe make a match untuk meningkatkan hasil belajar matematika siswa kelas IV SD negeri 2 Gayau Sakti tahun pelajaran 2014/2015 [The implementation of cooperative learning model of make a match type for increasing the fourth grade students' mathematics learning outcome of SD Negeri 2 Gayau Sakti State Elementary School in 2014/2015]. Aksioma, 5(1), 68-74.

Stauffer, W. (2013). The effects of cooperative learning on the academic achievement, social interaction, behavior, and affection of secondary English and social studies students. Thesis. Evergreen State College.

Sugiyono, S. (2007). Metode penelitian kuantitatif, kualitatif dan R\&D [Method for quantitative-qualitative and R\&D research]. Bandung: Alfabeta.

Ulfatin, N. (2013). Metode penelitian kualitatif di bidang pendidikan: Teori dan aplikasinya [Methodology of qualitative research of education: Theory and its application]. Malang: Banyumedia.

Wastawan, K., Sutarsyah, C. and Sudirman, S. (2014). Increasing students' reading comprehension through make a match type of cooperative learning at the first grade of SMA. Journal U-Jet, 3(2), 1-11.

Wieman, C. (2014). Stop lecturing me. Scientific American, 311, 70-71. https://doi.org/10.1038/Scientificamerican0814-70. 